\title{
A comparative study of continuous versus interrupted suturing for repair of episiotomy or second degree perineal tear
}

\author{
Lopamudra Jena*, Shyama Kanungo
}

Department of Obstetrics \& Gynaecology, S C B Medical College, Cuttack, Odisha, India

Received: 08 November 2014

Accepted: 10 December 2014

\author{
*Correspondence: \\ Dr. Lopamudra Jena, \\ E-mail: julijena82@gmail.com
}

Copyright: (C) the author(s), publisher and licensee Medip Academy. This is an open-access article distributed under the terms of the Creative Commons Attribution Non-Commercial License, which permits unrestricted non-commercial use, distribution, and reproduction in any medium, provided the original work is properly cited.

\begin{abstract}
Background: This study has been taken up to assess the effects of continuous versus interrupted suturing methods on the incidence of short and long term postpartum maternal morbidity experienced by women following repair of episiotomy or second-degree perineal tears after vaginal birth.

Methods: This comparative prospective study was conducted in department of obstetrics and gynaecology of S.C.B. medical college, Cuttack, Odisha to compare continuous suturing technique with interrupted method for the repair of episiotomy and second degree perineal tear following vaginal delivery in 211 women. One group was repaired with continuous non-locking sutures involving the vaginal mucosa, perineal muscles and subcutaneous tissue for skin and other group had continuous locking stitch of vaginal mucosa, interrupted sutures in perineal muscles and interrupted transcutaneous stitches for skin. Identical suture material (catgut supplied by the government) was used for both the groups. The mothers were interviewed on the $2^{\text {nd }}, 10^{\text {th }}$ and $42^{\text {nd }}$ day following repair regarding pain perception with lying, walking and sitting posture using Visual Analogue Scale (VAS).

Results: The pain score measured by VAS on $2^{\text {nd }}$ day showed mild to moderate pain in continuous group compared to moderate and severe pain in interrupted group $(\mathrm{P}=0.008)$ in lying position and $(\mathrm{P}=0.000)$ in sitting and walking position. On $10^{\text {th }}$ day no difference in perception in lying position $(\mathrm{P}=0.571)$ but more subjects of interrupted group had pain in sitting and walking position $(\mathrm{P}=0.05)$. On $42^{\text {nd }}$ day no difference in pain perception in both groups was seen $(\mathrm{P}=1.000)$. There was no difference in wound dehiscence in both the groups $(\mathrm{P}=0.361)$. Subjects in the interrupted group had greater complains of dyspareunia compared to subjects in continuous group $(\mathrm{P}=0.009)$. Less length of suture were required in the continuous group $(\mathrm{P}=0.000)$.

Conclusions: Continuous suturing technique for repair of episiotomy and second degree of perineal tear compared to interrupted methods are associated with less short term pain, dyspareunia and amount of suture material used is also less but there is no difference in daily work after 42 days and incidence of wound dehiscence.
\end{abstract}

Keywords: Episiotomy, Perineal tears, Visual analogue scale, Continuous suturing, Interrupted suturing

\section{INTRODUCTION}

Evolution is a significant truth of existence, so whatever methods or techniques of surgery are developed evolved over time and not withstanding episiotomy. Episiotomy the surgical incision made on the perineum to reduce the soft tissue resistance of the outlet and to straighten the pelvic canal that facilitates delivery. ${ }^{1}$ The first recorded episiotomy occurred in Scotland in 1740s. ${ }^{2}$ The procedure was not put to wide use in mid 1900s, when doctors in United States began to believe that the routine use of episiotomy would increase the speed of labour, prevent trauma or tearing to the vagina and prevent relaxation of the pelvic floor muscles, thereby preventing urinary and fecal incontinence. The policy of routine episiotomy should be abandoned in favour of policy of selective episiotomy. ${ }^{3}$ 
A recent prospective observational study revealed that 78 percent of women had a tear during child birth. ${ }^{4}$ It is estimated that over 85 percent of women who have spontaneous vaginal birth will sustain some form of perineal trauma and of these $60-70$ percent will require suturing. ${ }^{4}$

The technique of suturing perineal trauma following childbirth may have a significant effect on the extent and degree of morbidity experienced by women both in short and long term. For more than 70 years, researchers have been suggesting that continuous non locking suture techniques for the repair of vagina, perineal muscle and skin are far better than the traditional interrupted methods in terms of reduced postpartum pain and yet they have not been generally used. ${ }^{5}$

This study has been taken up to assess the effects of continuous versus interrupted suturing methods on the incidence of short and long term postpartum maternal morbidity experienced by women following repair of episiotomy or second-degree perineal tears after vaginal birth.

The evidence collated in this study will throw light to choose the most appropriate technique of perineal repair in terms of both health gain and cost.

The main outcomes of interest studied are short and long term pain, amount of suture material used, intromission dyspareunia and resuturing of wound.

\section{METHODS}

The study was conducted in the department of obstetrics and gynaecology of S. C. B. medical college, Cuttack, Odisha.

211 patients of variable age groups and parity with term pregnancy were enrolled in the study. The period of study was from June 2009 to December 2011.

\section{Inclusion criteria}

1) Vaginal birth with or without instrumentation

2) Pregnancy of atleast 37 weeks gestation

3) An episiotomy involving the skin and muscle but not the anal sphincter or rectum

4) Aviable new-born without serious congenital malformation

\section{Exclusion criteria}

1) Factors interfering with wound healing like severe anaemia, diabetes mellitus or patients on corticosteroids or immune-suppressants

2) Epidural labour analgesia which affects post-partum pain perception
This is a prospective comparative study between continuous and interrupted suturing used for episiotomy repair. All patients of reproductive age group with episiotomy or perineal tears are enrolled in this study after taking their consent. Suture material used in both the groups was same i.e. absorbable chromic catgut no1-0 which is supplied by the government.

One group was repaired with continuous, non-locking sutures involving the vagina, perineal muscles and subcutaneous tissue for skin.

The other group had continuous locking sutures of vagina, interrupted sutures in the perineal muscle and interrupted transcutaneous sutures. Patients were not aware of the type of suturing done.

Mothers were interviewed on $2^{\text {nd }}, 10^{\text {th }}, 42^{\text {nd }}$ day following repair regarding pain perception with lying, walking and sitting postures using visual analogue scale. Besides this the number of sutures used, wound dehiscence and dyspareunia were also compared.

The statistical analysis of the data collected was done using SPSS 13 software. The results were analysed using Chi-square test and Mann Whitney U test.

\section{RESULTS}

A total of 211 women having either episiotomy or second degree perineal tear were selected with their consent, out of which 105 women had their perineum repaired by continuous technique and 106 women had their perineum repaired by interrupted technique. Almost equal number of subjects with similar age group and parity were taken in both study groups. The pain score measured by VAS on $2^{\text {nd }}$ day, $10^{\text {th }}$ day $\& 42^{\text {nd }}$ day of puerperium is reflected (Table 1).

The pain score measured on the $2^{\text {nd }}$ day in lying position showed $51.9 \%$ subjects in the interrupted group had moderate to severe pain compared to $20 \%$ in continuous group $(\mathrm{P}=0.008)$. On $2^{\text {nd }}$ day in sitting and walking position $51.9 \%$ subjects in interrupted group had pain in comparison to $20 \%$ in continuous group $(\mathrm{P}=0.000)$. Pain score measured on $10^{\text {th }}$ day in lying position showed $68.7 \%$ of subjects had no pain $(\mathrm{P}=0.571)$. Pain score measured on $10^{\text {th }}$ day in sitting and walking showed $70.5 \%$ subjects in continuous group had no pain compared to $56.6 \%$ in interrupted group. Incidence of mild to moderate pain was more in interrupted group $43.4 \%$ compared to $29.6 \%$ in continuous group $(\mathrm{P}=$ $0.024)$. Pain score measured on $42^{\text {nd }}$ day in lying, sitting and walking positions showed no pain in all subjects of both the groups $(\mathrm{P}=1.000)$. No difference in number of wound dehiscence in both groups noticed $(\mathrm{P}=0.361)$ (Table 2).

Subjects in interrupted group had greater complains of dyspareunia (73\%) compared to subjects in continuous 
group (27\%), $\mathrm{P}=0.009$ (Table 3). Comparison of number of sutures used showed less suture was used in continuous group as compared to interrupted group $(\mathrm{P}=$ 0.000) (Table 4).

Table 1: Mann-Whitney Test for comparing suturing techniques and pain in postpartum days $2^{\text {nd }}, 10^{\text {th }}, 42^{\text {nd }}$.

\begin{tabular}{|c|c|c|c|c|c|}
\hline Pain & $\begin{array}{l}\text { Suturing } \\
\text { type }\end{array}$ & $\mathbf{N}$ & $\begin{array}{l}\text { Mean } \\
\text { rank }\end{array}$ & $\begin{array}{l}\text { Mann } \\
\text { Whitney } \\
\text { U }\end{array}$ & $\begin{array}{l}2 \\
\text { sided } \\
\mathbf{P} \\
\text { value }\end{array}$ \\
\hline \multirow{2}{*}{$\begin{array}{l}\text { Pain in } 2^{\text {nd }} \\
\text { day in } \\
\text { lying } \\
\text { position }\end{array}$} & Continuous & 105 & 97.00 & \multirow{2}{*}{4619.5} & \multirow{2}{*}{0.009} \\
\hline & Interrupted & 106 & 114.92 & & \\
\hline \multirow{2}{*}{$\begin{array}{l}\text { Pain in } 2^{\text {nd }} \\
\text { day in } \\
\text { sitting } \\
\text { position }\end{array}$} & Continuous & 105 & 88.95 & \multirow{2}{*}{3775} & \multirow{2}{*}{0.000} \\
\hline & Interrupted & 106 & 122.89 & & \\
\hline \multirow{2}{*}{$\begin{array}{l}\text { Pain in } 2^{\text {nd }} \\
\text { day in } \\
\text { walking } \\
\text { position }\end{array}$} & Continuous & 105 & 88.95 & \multirow[b]{2}{*}{3775} & \multirow[b]{2}{*}{0.000} \\
\hline & Interrupted & 106 & 122.89 & & \\
\hline \multirow{2}{*}{$\begin{array}{l}\text { Pain in } \\
10^{\text {th }} \text { day in } \\
\text { lying } \\
\text { position }\end{array}$} & Continuous & 105 & 103.87 & \multirow[b]{2}{*}{5341.5} & \multirow[b]{2}{*}{0.532} \\
\hline & Interrupted & 106 & 108.11 & & \\
\hline \multirow{2}{*}{$\begin{array}{l}\text { Pain in } \\
10^{\text {th }} \text { day in } \\
\text { sitting } \\
\text { position }\end{array}$} & Continuous & 105 & 98.13 & \multirow{2}{*}{4738.5} & \multirow{2}{*}{0.027} \\
\hline & Interrupted & 106 & 113.80 & & \\
\hline \multirow{2}{*}{$\begin{array}{l}\text { Pain in } \\
10^{\text {th }} \text { day in } \\
\text { walking } \\
\text { position }\end{array}$} & Continuous & 105 & 98.13 & \multirow{2}{*}{4738.5} & \multirow{2}{*}{0.027} \\
\hline & Interrupted & 106 & 113.80 & & \\
\hline \multirow{2}{*}{$\begin{array}{l}\text { Pain in } \\
42^{\text {nd }} \text { day in } \\
\text { lying } \\
\text { position }\end{array}$} & Continuous & 105 & 106.0 & \multirow{2}{*}{5565} & \multirow{2}{*}{1.000} \\
\hline & Interrupted & 106 & 106.0 & & \\
\hline \multirow{2}{*}{$\begin{array}{l}\text { Pain in } \\
42^{\text {nd }} \text { day in } \\
\text { sitting } \\
\text { position }\end{array}$} & Continuous & 105 & 106.0 & \multirow{2}{*}{5565} & \multirow{2}{*}{1.000} \\
\hline & Interrupted & 106 & 106.0 & & \\
\hline \multirow{2}{*}{$\begin{array}{l}\text { Pain in } \\
42^{\text {nd }} \text { day in } \\
\text { walking } \\
\text { position }\end{array}$} & Continuous & 105 & 106.0 & \multirow{2}{*}{5565} & \multirow{2}{*}{1.000} \\
\hline & Interrupted & 106 & 106.0 & & \\
\hline
\end{tabular}

Table 2: Comparison of wound dehiscence with suturing technique.

\begin{tabular}{|c|c|c|c|}
\hline \multirow{2}{*}{$\begin{array}{l}\text { Wound } \\
\text { dehiscence }\end{array}$} & \multicolumn{2}{|c|}{ Suturing technique } & \multirow{2}{*}{ Total } \\
\hline & Continuous & Interrupted & \\
\hline Yes & $4(3.8 \%)$ & $7(6.6 \%)$ & $11(5.2 \%)$ \\
\hline No & $101(96.2 \%)$ & $99(93.4 \%)$ & $200(94.7 \%)$ \\
\hline
\end{tabular}

Chi square $\mathrm{P}$ value $=0.361$
Table 3: Comparison of dyspareunia with suturing technique.

\begin{tabular}{|llll|}
\multirow{2}{*}{ Dyspareunia } & \multicolumn{2}{l}{ Suturing technique } & \multicolumn{1}{l}{ Total } \\
& Continuous & Interrupted & \\
\hline Yes & $20(19 \%)$ & $37(34.9 \%)$ & $57(27 \%)$ \\
\hline No & $85(81 \%)$ & $69(65 / 1 \%)$ & $154(73 \%)$ \\
\hline
\end{tabular}

Chi square $\mathrm{P}$ value $=0.009$

Table 4: Comparison of number of sutures according to suturing technique.

\begin{tabular}{|c|c|c|c|}
\hline \multirow{2}{*}{$\begin{array}{l}\text { Number of } \\
\text { sutures used }\end{array}$} & \multicolumn{2}{|c|}{ Suturing technique } & \multirow{2}{*}{ Total } \\
\hline & Continuous & Interrupted & \\
\hline 1 & $93(88.6 \%)$ & $28(26.4 \%)$ & $121(57.3 \%)$ \\
\hline 2 & $12(11.4 \%)$ & $62(58.5 \%)$ & $74(35.1 \%)$ \\
\hline 3 & 0 & $16(15.1 \%)$ & $16(7.6 \%)$ \\
\hline Total & $105(100 \%)$ & $106(100 \%)$ & $211(100 \%)$ \\
\hline
\end{tabular}

Chi square $\mathrm{P}$ value $=0.000$

\section{DISCUSSION}

In this study, the differences between the continuous suturing group and the interrupted suturing group were uses of less suture material. Short term pain was less in continuous suturing group and long term complains of pain were similar between the two groups. More dyspareunia (three times more) was seen in interrupted group but the incidences of wound dehiscence were same in both the groups.

Kettle et al. carried out a trail comparing the two techniques of episiotomy repair (continuous and discontinuous) using two suture materials (quick absorption and standard) and found that less pain was experienced with the continuous suture technique. ${ }^{6}$

In this comparative study, in the two groups of women, the ability of health professionals and the type of materials used were the same. The only difference was the suture technique. Less suture material used and less short term postpartum pain were the significant differences between the two groups. Our results were same as the recent meta-analysis of the Cochrane database. $^{7}$

Almeida SF, Rieco MI compared the continuous and interrupted techniques and found more pain in interrupted suture technique. ${ }^{8}$ Mota R, Costa F published their experience in the use of the two suture techniques, use of adhesive glue and subcuticular suture in repairing the skin and suggested that the adhesive glue was associated with a lower degree of pain in the perineum compared with other more traditional method. ${ }^{9}$

Thus in conclusion, continuous suturing techniques for perineal closure are associated with less short term pain. However, if the continuous technique is used for all 
layers (vagina, perineal muscles and skin), the benefit in terms of reducing pain is even greater. The continuous technique is easily performed by the novice or inexperienced operator. In addition, it has economical advantages that the continuous technique requires less suture material compared to interrupted method. Therefore the continuous nonlocking suturing technique is recommended for repair of vagina and perineal muscles with a continuous subcutaneous stitch to close the perineal skin.

Funding: No funding sources Conflict of interest: None declared

Ethical approval: The study was approved by the institutional ethics committee

\section{REFERENCES}

1. Penna LK. Episiotomy. In: Arulkumaran S, Penna LK, Rao BK, eds. the Management of Labour. 2nd ed. Chennai: Orient Longman Publishers; 2005: 157.

2. David M. Who invented the episiotomy? On the history of the episiotomy. Zentralbl Gynaecol. 1993;115(4):188-93.

3. Argentine Episiotomy Trial Collaborative Group. Routine vs. selective episiotomy: a randomised control trail. Lancet. 1993;342(8886-8887):1517-8.

4. Sleep J, Grant A, Gracia J, Elbourne D, Spencer J, Chalmers I. West Berkshire perineal management trail. Br Med J (Clin Res Ed). 1984;289(6445):58790.

5. Weber AM, Meyn L. Episiotomy use in the United States, 1979-1997. Obstet Gynaecol. 2002;100(6):1177-82.

6. Kettle C, Dowswell T, Ismail KM. Absorbable suture materials for primary repair of episiotomy and second degree tears. Cochrane Database Syst Rev. 2010;16(6):CD000006.

7. Kettle C, Hills RK, Ismail KM. Continuous versus interrupted sutures for repair of episiotomy or second degree tears. Conchrane Database Syst Rev. 2007;17(4):CD000947.

8. Almeida SF, Reesco ML. Randomised controlled clinical trial on two perineal trauma suture techniques in normal delivery. Rev Lat Am Enfermagem. 2008;16(2):272-9.

9. Mota R, Costa F, Amaral A, Oliveira F, Santos CC, Ayres-De-Campos D. Skin adhesive versus subcuticular suture for perineal skin repair after episiotomy: a randomised control trial. Acta Obstet Gynaecol Scand. 2009;88(6):660-6.

DOI: $10.5455 / 2320-1770$. ijrcog20150210

Cite this article as: Jena L, Kanungo $\mathrm{S}$. A comparative study of continuous versus interrupted suturing for repair of episiotomy or second degree perineal tear. Int J Reprod Contracept Obstet Gynecol 2015;4:52-5. 